\title{
Fermín Bouza, In memoriam
}

El 29 de octubre del pasado año falleció Fermín Bouza Álvarez en Madrid, debido a una inesperada broma del azar, una infección postoperatoria que acabó en septicemia; inexplicable, como numerosas cosas en la vida y sobre lo que tantas veces habíamos hablado.

Conocí a Fermín Bouza el curso 1992-93 como profesor en el programa de doctorado que realizaba en Madrid, y fue, además, mi director de tesis. La tesis versaba sobre la configuración del área metropolitana de Valencia, línea de investigación alejada de sus intereses profesionales, como Catedrático de Opinión Pública que era, pero, sin duda, la sentía cercana por el hecho de haber pasado parte de su juventud en Valencia estudiando en la Facultad de Físicas. Así, los recuerdos de juventud, siempre agradables y muchas veces nostálgicos, y el hecho de mostrar interés por los cambios acaecidos en lo que él todavía denominaba «la huerta valenciana» le animaron a dirigirme la tesis, mostrándose siempre dispuesto a contestar mis dudas en todos los aspectos que conlleva la elaboración y redacción de una tesis doctoral.

Desde entonces, sus visitas a la Universitat Jaume I de Castellón y en concreto, al Departamento de Filosofía y Sociología, fueron continuas y habituales. Le invitábamos a dar conferencias, a participar en cursos, a presidir tribunales de tesis doctorales o de plazas docentes, a ser miembro del comité científico de la revista Recerca. Revista de Pensament $i$ anàlisi, y a codirigir tesis doctorales. Generoso siempre en su disponibilidad a venir a Castellón, su generosidad se repetía en cada viaje que yo realizaba a Madrid, dispuesto a invitarme a comer cada vez que allí me desplazaba; las comidas, siempre de pescado y vino blanco gallego, albariño o del Rosal. Junto a estos placeres, una conversación enriquecedora y un estar cómodo y relajado. Menos mal que cuando venía a Castellón nos dejaba invitarle y disfrutaba también del pescado mediterráneo y de los caldos valencianos.

Sus análisis políticos eran esclarecedores y siempre estaba atenta a sus comentarios escritos o hablados, a su blog El voto con botas o a su participación en obras académicas. Previo a las elecciones, siempre le preguntaba «Fermín, ¿cómo lo ves? ¿Cómo está la cosa?», a lo que me respondía rápidamente, dándome su opinión sincera y sin tapujos; o manifestaba cierto es- 
cepticismo ante lo sucedido entre las dos últimas consultas electorales. No obstante, y cuando en ocasiones le comentaba cuitas laborales o personales, su frase habitual era «p'alante, Merce, p'alante».

La noticia de su fallecimiento me pilló fuera de España, me llegó por whatsapp, medio de comunicación rápido, pero frío, y el corazón me dio un vuelco. La frialdad del medio chocó con el impacto emocional que sentía y la ciudad bella y acogedora donde me encontraba me pareció lejana.

Del profesor Fermín Bouza echaré en falta su conversación, su mirada noble y transparente, su saber escuchar atentamente y su afecto. Desde aquí, mi agradecimiento por el trato afable y el apoyo que me dio siempre. Descansa en paz, Fermín. 